\title{
DA ANGÚSTIA À FELICIDADE: \\ CAMINHOS TECNOLÓGICOS DE PROFESSORES NA PANDEMIA
}

FROM ANGUISH TO HAPPINESS:

TECHNOLOGICAL PATHS OF TEACHERS IN THE PANDEMIC

DE LA ANGUSTIA A LA FELICIDADE:

CAMINOS TECNOLÓGICOS DE LOS PROFESSORES EN LA PANDÉMIA

Heloisa Paes de Barros Arruda ${ }^{1}$

Ana Maria Di Grado Hessel ${ }^{2}$

\section{RESUMO}

O presente artigo tem como objetivo analisar os sentimentos e suas situações indutoras a partir da experiência de cinco professores do ensino fundamental da Rede Municipal de São Paulo com as aulas remotas. A pesquisa qualitativa discute as situações pedagógicas de que mais gostaram e aquelas de que menos gostaram no contexto da pandemia (Covid-19) de aulas mediadas pelas Tecnologias Digitais da Informação e Comunicação (TDIC). Os dados foram coletados em agosto de $2020 \mathrm{com}$ questionário formado por perguntas abertas e discutidos à luz da teoria de Henri Wallon por meio da análise de conteúdo, que mostraram a amplitude de sentimentos positivos e negativos relacionados à situação inusitada das aulas remotas. Sentimentos variados foram identificados: ansiedade e angústia pela situação nova e imediata das aulas mediadas pelas TDIC, a felicidade e satisfação dos docentes pela participação dos alunos na aula síncrona, a alegria de alunos, que compreenderam o conteúdo. Alunos e professores, pessoas que devem ser observadas em sua integralidade, manifestam suas necessidades afetivas, cognitivas e motoras durante o processo de ensino-aprendizagem. Compreendendo essas necessidades, poderemos atendê-las e proporcionar um melhor aproveitamento nas situações pedagógicas.

PALAVRAS-CHAVE: Ensino-aprendizagem. Tecnologias. Afetividade. Pandemia. COVID-19.

\section{ABSTRACT}

The present article aims to analyze the feelings and their inducing situations from the experience of five elementary school teachers from the São Paulo Municipal Network with remote classes. The qualitative research discusses the pedagogical situations they liked best and those they liked least in the context of the pandemic (Covid-19) of classes mediated by Digital Information and Communication Technologies (ICT).

\footnotetext{
${ }^{1}$ Submetido em:27/05/2021 - Aceito em: 06/09/2021 - Publicado em: 17/12/2021
}

1 Doutora em Educação e Currículo pela PUC-SP.

2 Doutora em Educação e Currículo pela PUC-SP, professora do Departamento de Educação da PUC/SP e professora credenciada do Programa de Estudos Pós-Graduados em Tecnologias da Inteligência e Design Digital (TIDD/PUCSP). 


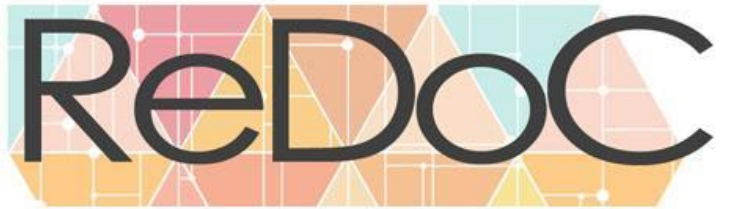

\section{Revista Docência e Cibercultura}

Data were collected in August 2020 with a questionnaire consisting of open-ended questions and discussed in the light of Henri Wallon's theory through content analysis, which showed the range of positive and negative feelings related to the unusual situation of remote classes. Varied feelings were identified: anxiety and anguish for the new and immediate situation of the classes mediated by the ITC, the happiness and satisfaction of teachers for the students' participation in the synchronous class, the joy of students, who understood the content. Students and teachers, people who must be observed in their entirety, manifest their affective, cognitive, and motor needs during the Teaching \& Learning process. By understanding these needs, we will be able to fulfill them and provide a better use of the pedagogical situations.

KEYWORDS: Teaching \& Learning. Technologies. Affectivity. Pandemic. COVID-19.

\section{RESUMEN}

El presente artículo tiene como objetivo analizar los sentimientos y las situaciones que los inducen a partir de la experiencia de cinco profesores de primaria de la Red Municipal de São Paulo con clases a distancia. La investigación cualitativa analiza las situaciones pedagógicas que más y menos les gustaron en el contexto de la pandemia (Covid-19) de las clases mediadas por las Tecnologías Digitales de la Información y la Comunicación (TIC). Los datos se recogieron en agosto de 2020 con un cuestionario formado por preguntas abiertas que se discutieron a la luz de la teoría de Henri Wallon mediante un análisis de contenido, que mostró la gama de sentimientos positivos y negativos relacionados con la situación inusual de las clases a distancia. Se identificaron sentimentos variados: la ansiedad y la angustia por la situación nueva e inmediata de las clases mediadas por las TIC, la alegría y la satisfacción de los profesores por la participación de los alumnos en la clase sincrónica, la alegría de los alumnos, que han entendido el contenido. Alumnos y profesores, personas que deben ser observadas en su totalidad, manifiestan sus necesidades afectivas, cognitivas y motrices durante el proceso de enseñanza-aprendizaje. Comprendiendo estas necesidades, podemos satisfacerlas y proporcionar un mejor uso en situaciones pedagógicas.

PAlabras ClaVe: Enseñanza-aprendizaje. Tecnologías. Afectividad. Pandemia. COVID-19.

Será que essa escola não vai cortar minha asa? Será que eu vou fazer algum amigo aqui? Será que ele também tem medo de dormir?

Será que será todo dia assim? Medo de ser o que o mundo espera de mim Será que eu vou fazer Algum amigo aqui?

Conto o tempo que falta Quando eu mesmo serei $\mathrm{O}$ autor da minha história?

Será que eu vou fazer

Algum amigo aqui?

Pela primeira vez

Eu fiz o caminho inteiro sozinho e a pé

Será que agora sim

Todo mundo faz o que gosta e o que quer? 
Revista Docência e Cibercultura

\author{
Sabendo que pra crescer \\ Algo terá que morrer ou ficar para trás
}

("Eu e o muro", Barbatuques, 2018)

\title{
INTRODUÇÃO
}

A humanidade foi afetada pelo novo coronavírus. No Brasil, vemos como a existência de muitas vidas está sob ameaça quando a marca de 454.000 mortes foi atingida em 24 de maio de 2021. Tantas mortes é algo muito preocupante e, se vemos essa situação em conjunto com dados como o do Índice de Desenvolvimento Humano (IDH) de 0,765 (o Brasil ocupa, então a 84 posição em 2020), observamos a necessidade de melhoria nas condições de vidas, por exemplo, no acesso à educação e saúde dos aproximadamente 211,7 milhões de brasileiros (dado estimado pelo IBGE) ${ }^{3}$.

Na música "Eu e o muro", de autoria de Charles Raszl, do grupo Barbatuques, que narra o crescimento de uma criança e os desafios de entrar em uma nova escola, podemos observar um retrato de parte das situações vivenciadas por alunos e professores. Vimos um cenário de incerteza e insegurança nas escolas de todo país provocado pela necessidade do isolamento social, confinamento em casa e suspensão das aulas presenciais a partir de março de 2020 (Decreto n 64.864, de 16 de mar. de 2020 - Estado de São Paulo). Professores, fazendo história e sendo autores de uma nova maneira de ensinar, se perguntaram: como abordar a amizade neste contexto? Qual caminho no uso das tecnologias nas aulas? O que vai ficar para trás e morrer? O que gostam e querem?

O contexto em 2019 já trazia as dificuldades enfrentadas por professores para o uso das Tecnologias Digitais da Informação e Comunicação (TDIC) em atividades pedagógicas. Podemos citar seis dificuldades principais: número insuficiente de computadores por aluno (72\%); número insuficiente de computadores conectados à Internet (68\%); equipamentos obsoletos ou ultrapassados (65\%); baixa velocidade de conexão à Internet (63\%); ausência de suporte técnico e manutenção dos equipamentos (58\%) e ausência de curso específico para o uso do computador e da Internet nas aulas (53\%). Entretanto, mesmo com todas essas dificuldades, $82 \%$ dos professores que lecionam em escolas urbanas afirmaram utilizar a Internet para desenvolver ou aprimorar conhecimentos sobre o uso de tecnologias nos processos de ensino e de aprendizagem (CETIC, 2020).

\footnotetext{
${ }^{3}$ Dados do Human Development Report 2020, disponível em: <http://hdr.undp.org/sites/default/files/hdr2020.pdf> Acesso em: 10 de abr. 2021.
} 


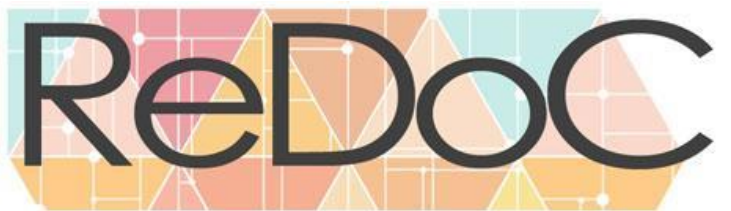

\title{
Revista Docência e Cibercultura
}

No Município de São Paulo, as aulas presenciais estavam suspensas desde março de 2020, sendo retomadas em fevereiro de 2021, ainda que com poucos alunos e orientadas por medidas protocolares (resolução SEDUC n.11, de 26 de janeiro de 2021, Estado de São Paulo). Todavia, com o agravamento da doença, no mês seguinte, as aulas presenciais foram suspensas novamente no município de São Paulo, antecipando o recesso (Instrução Normativa SME n. 7, de 12 de março de 2021). Neste sentido, o ensino híbrido ganhou a pauta de discussões na educação, recebeu diferentes definições e os professores estiveram cercados de muitas dúvidas sobre o que fazer.

Segundo Barcelos e Batista (2019), os desafios para a implementar o ensino híbrido são:

\begin{abstract}
i) acesso à Internet de qualidade na escola e fora dela; ii) o hábito dos alunos de receberem as informações de forma expositiva desde os anos iniciais da educação formal; iii) a falta de tempo dos professores, decorrente de suas diversas atribuições, aspecto que entra em conflito com o tempo necessário para o planejamento das atividades e elaboração de materiais; iv) turmas com muitos alunos, o que dificulta a personalização do ensino. Nesse sentido, propostas de Ensino Híbrido em formatos que não provoquem mudanças bruscas no cenário educacional tradicional tendem a ter melhor receptividade. (BARCELOS; BATISTA, 2019, p.65)
\end{abstract}

Neste cenário educacional atual abruptamente impactado, cada pessoa foi afetada positiva e negativamente pelo mundo/meio que a rodeia, interna e externamente.

De forma dialética, nas tensões e conflitos, os homens sofrem influência e também influenciam as questões da sociedade. "Como indivíduo o homem está sujeito às condições de seu ambiente físico e social [...] mas ele é o artesão que modificando o meio físico obriga a transformação do meio social e, assim, se transforma a si mesmo." (WALLON, 1936, p.14 apud PRANDINI, 2020, p.23). Dentre as questões sociais, a imposição de uso das TDIC para possibilitar alguma relação entre alunos e professores fez-se presente, mesmo identificando que os obstáculos para sua utilização eram grandes e já apontados em 2019 (CETIC, 2020). Esta situação prévia provocou diversos sentimentos nos professores implicados no processo de ensinoaprendizagem.

Ademais, a presença dos artefatos tecnológicos na cultura digital e o impacto/integração na educação é histórico e pesquisado por diversos autores ao longo dos últimos anos, por meio, por exemplo, do estudo de questões relacionadas à evolução das TDIC, às políticas públicas de inserção nas escolas, ao web currículo e às diversas mudanças na forma de pensar, sentir, movimentar e agir (SANTAELLA, 2020; SANTOS, 2019; ALMEIDA e SILVA, 2011; ALMEIDA, ELIZABETH e VALENTE, 2016; KENSKI, 2003; LITTO e FORMIGA, 2009; ALMEIDA e FRANCO, 2013 COLL e MONEREO, 2010). 
O objetivo do presente artigo é divulgar a análise e os resultados de pesquisa qualitativa sobre os sentimentos de cinco professores do fundamental de uma escola da rede Municipal de São Paulo, antes e depois das aulas síncronas, bem como situações pedagógicas de que mais gostaram e aquelas de que menos gostaram no contexto da pandemia (Covid-19) de aulas mediadas pelas TDIC. Os dados foram discutidos à luz da teoria de Henri Wallon por meio da análise de conteúdo (FRANCO, 2003).

Percebe-se que os sentimentos dos professores e suas situações indutoras são importantes componentes para um efetivo processo de ensino-aprendizagem. É necessário atender às necessidades afetivas de professores e alunos, pois tais estados emocionais têm implicações nos domínios cognitivo e motor.

O texto está organizado em cinco sessões: a primeira apresenta o conceito de afetividade para Henri Wallon (1981); a segunda apresenta os sentimentos (de cinco professores que atuam no ensino fundamental) relacionados às suas práticas pedagógicas mediadas por TDIC durante a pandemia, e também os sentimentos que identificaram nos seus alunos; a terceira, sobre atividades de que mais gostaram; a quarta, sobre as atividades de que menos gostaram e porquê; e, por último, as considerações finais.

\section{AFETIVIDADE POR HENRI WALON}

\section{Afetividade para Henri Wallon}

Henri Wallon (1879-1962), médico, psicólogo e filósofo, deixou diversas lições para os educadores. Mahoney e Almeida (2002) destacam duas importantes,

Somos pessoas completas: com afeto, cognição e movimento, e nos relacionamos com um aluno também pessoa completa, integral, com afeto, cognição e movimento. Somos componentes privilegiados do meio de nosso aluno. Torná-lo mais propicio ao desenvolvimento é nossa responsabilidade. (MAHONEY; ALMEIDA, 2002, p. 86)

Wallon tem como alicerce de sua teoria o materialismo histórico dialético e concebe o ser humano de forma integrada: tanto na relação organismo-meio, quanto dos conjuntos funcionais cognitivo, afetivo, motor e pessoa. Esse último, pessoa, "expressa a integração em todas as suas inúmeras possibilidades." (MAHONEY; ALMEIDA, 2005, p. 18). Durante todo o 


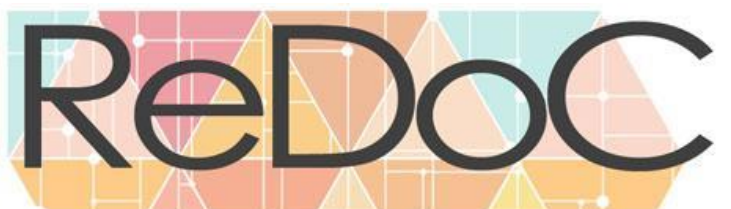

\section{Revista Docência e Cibercultura}

desenvolvimento de nossas vidas, os conjuntos funcionais sempre estão presentes e interferindo um no outro.

Para melhor compreender o aspecto da afetividade da integração funcional do sujeito enquanto um artifício didático faremos uma descrição a seguir. A afetividade é a capacidade de a pessoa ser afetada, positiva ou negativamente, pelo mundo que se localiza dentro e fora dela. As reações pelas situações vividas podem ser de prazer, bem-estar e desprazer ou mal-estar. Vontades, interesses, valores, necessidades e motivações, pertencem ao seu âmbito e, portanto, ditam decisões e escolhas. Sendo assim, a afetividade é a energia que mobiliza a pessoa a agir, dando direção ao cognitivo e motor. Evolui do orgânico ao moral e comporta três momentos sucessivos: emoção, sentimentos e paixão.

A emoção é orgânica, é a exteriorização da afetividade, é fugaz, intensa e sem controle. Possui três características: o contágio, a plasticidade e a comunicação que são recursos para a sociabilidade. É no tônus muscular que enxergamos a expressão da afetividade: testa enrugada expressando preocupação, ou um rosto vermelho expressando timidez, ou ainda um choro estridente de um bebê recém-nascido que tem fome e é sua única forma de comunicar.

Dependendo da intensidade da emoção, ela tem o poder de fazer regredir a atividade intelectual, que se obnubila. Já os sentimentos, são menos intensos, mais duradouros, mais controlados e prepondera o cognitivo, a representação é o seu componente. Por isso, é um estágio mais tardio da evolução, são mais complexos e elaborados. Quando as emoções são nomeadas, verbalizadas e descritas, estamos no domínio dos sentimentos - é o caso, por exemplo, de quando a criança verbaliza "estou triste porque meu cachorro morreu" ou escreve no diário "estou feliz porque ganhei um presente". Por fim, a paixão (diferente do entendimento do senso comum) tem o poder de tornar a emoção silenciosa, porque implica em autocontrole sobre ela. É mais duradoura, mais encoberta e mais focada.

Portanto, o papel da afetividade no processo de ensino-aprendizagem é de suma importância:

O processo ensino-aprendizagem é o recurso fundamental do professor: sua compreensão, e o papel da afetividade nesse processo, é um elemento importante para aumentar a sua eficácia, bem como para a elaboração de programas de formação de professores. (MAHONEY;ALMEIDA, 2005, p.12)

Uma pesquisa constatou os sentimentos e emoções de alunas (professoras em formação) que estariam implicados na relação com o professor e interferiam no processo de ensino e aprendizagem mediado pelas TDIC (ARRUDA, 2012). Colocou em relevo as seguintes 


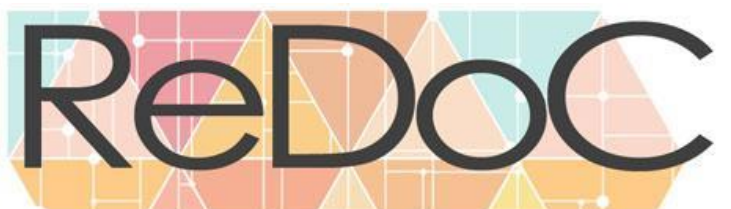

Revista Docência e Cibercultura

questões: elementos que interferem negativamente foram relatados pelas alunas. Tais como: insatisfação com a postura e expressão do videoconferencista enquanto esperava que as alunas realizassem os exercícios, pois, estava esperando por respostas que não vinham; ansiava por possíveis perguntas, o que gerava constrangimento; outra constatação diz respeito ao tom de voz único, incômodo; há relato de incômodo e culpa pela não participação das alunas; a insatisfação e tédio foi por conta da intensa repetição sobre a explicação do conteúdo; além dos problemas técnicos, tais como som abafado, letras pequenas, projeção de filmes com má qualidade técnica. Já aqueles que interferem positivamente foram destacados pelas alunas: 0 fato de os professores fazerem o levantamento dos conhecimentos prévios das alunas, pois há satisfação ao poderem falar sobre o que já sabiam sobre o assunto; além de ser considerado satisfatório a projeção de filmes (ARRUDA, 2012).

\section{Percurso da pesquisa}

A presente pesquisa qualitativa é de campo e exploratória. O critério de escolha dos sujeitos foi a disponibilidade em participar da pesquisa. Os cinco professores (P1, P2, P3, P4, P5) atuam na mesma escola, a qual possui a nota 7 no IDEB $^{4}$. Quatro deles atuam nos anos iniciais do fundamental e um atua nos anos finais. P1 tem 36 anos, atua há 10 como professor e é o único que leciona nos anos finais do fundamental; P2 tem 36 anos e leciona há 16 anos; P3 tem 35 anos e leciona há 11 anos; P4 tem 36 anos e leciona há 10 anos; P5 tem 48 anos e leciona há 24 anos. Os dados foram coletados em agosto de 2020, por meio de perguntas abertas. Quatro entrevistados responderam as questões por áudio pelo whatsapp e um respondeu por escrito.

Com relação aos sentimentos, foi perguntado: "Ontem, antes de começar as aulas online com seus alunos, quais eram seus sentimentos?” e "Ontem, ou na última vez, após seu encontro virtual com seus alunos, quais eram seus sentimentos?". Sobre a atividade docente: "Me conte uma aula/atividade/sequência didática que você fez com seus alunos que você mais gostou. Por quê? Me conte o que aconteceu, como foi... propostas..." e "Me conte uma aula/atividade/sequência didática que você fez com seus alunos que você não gostou. Por quê? Me conte o que aconteceu, como foi...”. Por fim, com relação à percepção que tinham dos sentimentos dos alunos, foi perguntado: "Da sua percepção durante as aulas, quais são os sentimentos dos seus alunos em relação ao processo de aprendizagem deles."

\footnotetext{
${ }^{4}$ Índice de Desenvolvimento da Educação Básica, que possui uma escala de 0 a 10 e sintetiza dois conceitos, a aprovação escolar e o aprendizado em português e matemática
} 
Os dados foram discutidos à luz da teoria de Henri Wallon por meio da análise de conteúdo (FRANCO, 2003), três categorias foram criadas: sentimentos dos professores, prazer e desprazer. Elas são apresentadas a seguir.

\section{Reflexões sobre afetividade de professores}

\section{a. Sentimentos de cinco professores no contexto da pandemia}

Segundo o Instituto Península (2020), os oito sentimentos mais relatados por professores, de forma quantitativa, durante a pandemia em agosto/2020, foram os seguintes: ansiosos (64\%), sobrecarregados $(53 \%)$, cansados $(46 \%)$, estressados $(42 \%)$, frustrados $(34 \%)$, entediados (26\%), calmos (10\%), felizes (5\%). É interessante que tenha aparecido o sentimento de calmo, mesmo que numa porcentagem pequena, pois, para acalmarem seus alunos nos momentos turbulentos e instáveis pelos quais estamos passando, é preciso que os próprios professores se mantenham calmos.

Já na presente pesquisa, de ordem qualitativa, observa-se diversos sentimentos pelos cinco professores, que responderam com as seguintes palavras e/ou expressões: incerteza, insatisfação, preocupação, muito preocupados, angústia, satisfação, tristeza, angústia e ansiedade, feliz, afago no coração, muita ansiedade, "complicadas para mim", ansiedade, pensativa, surpresa, timidez, apreensiva, "um pouco mais calma", medo. Outra expressão que apareceu foi: "estar tentando fazer minha parte" como senso de responsabilidade que esta professora demonstrou.

Quadro 1. Sentimentos percebidos pelos professores e de alunos identificados pelos professores

\begin{tabular}{|l|l|l|l|}
\hline Professor & $\begin{array}{l}\text { Sentimentos antes da } \\
\text { aula }\end{array}$ & Sentimentos após a aula & Identificado nos alunos \\
\hline P1 & $\begin{array}{l}\text { Incerteza, insatisfação, } \\
\text { preocupação }\end{array}$ & & $\begin{array}{l}\text { Ansioso e impaciente, conscientes, } \\
\text { preocupados }\end{array}$ \\
\hline P2 & Angústia & Satisfação e tristeza & "Participação", "não participação" \\
\hline P4 & $\begin{array}{l}\text { Angústia e ansiedade } \\
\text { Puita ansiedade, "bem } \\
\text { mimplicadas para }\end{array}$ & Triste, feliz & Ansiedade, tranquila \\
\hline
\end{tabular}


Revista Docência e Cibercultura

\begin{tabular}{|l|l|l|l|}
\hline P5 & $\begin{array}{l}\text { "Pensativa", } \\
\text { "Surpresa" }\end{array}$ & $\begin{array}{l}\text { "tentando fazer a minha } \\
\text { parte" }\end{array}$ & $\begin{array}{l}\text { Felizes (hipótese: entediados, } \\
\text { cansados) }\end{array}$ \\
\hline
\end{tabular}

Fonte: autoras.

Observa-se no quadro 1, os sentimentos relatados por P1: incerteza, insatisfação e preocupação. Percebeu nos alunos: ansiosos e impacientes, preocupados e conscientes. P2: angústia, satisfação e tristeza e percebeu nos alunos participação e não participação. Já P3 relatou sentimentos de angústia e ansiedade, triste e feliz. Percebeu nos alunos alegria e participação. P4 percebeu nela muita ansiedade e "bem complicadas", tranquila. Já P5 relatou sentimentos de "pensativa", "surpresa, "tentando fazer a minha parte", e nos alunos: felizes. Antes da aula ela pensava se os alunos estariam entediados e cansados.

As situações indutoras destes sentimentos também foram diversas, ora relacionadas às aulas a distância e à novidade na utilização de recursos tecnológicos (angústia e ansiedade), ora à própria situação da pandemia e insegurança do momento (incerteza, insatisfação, preocupação), ora com relação ao material impresso curricular preparado pela Secretaria Municipal de Educação (gosto, não gosto e surpresa), ora do próprio processo de ensino e aprendizagem (triste) e ora da relação com os alunos na situação mediada pelas TDIC (feliz, afago no coração).

Discutir a afetividade nas interações em sala de aula leva a refletir como alunos e professores significam as experiências vividas. Coloca em relação o individual e o social. O que se faz, diz, pensa, sente, aprende referem-se a processos sociais que compõem a história de cada sujeito envolvido, assim como este também interfere na constituição do contexto em que as situações ocorrem. [...] os sentimentos são sinalizadores que mostram como o indivíduo está sendo afetado (WALLON, 1995a). Portanto, as experiências vividas em sala de aula evocam sentimentos, que vão marcando as relações dos alunos com o conhecimento. (TASSONI, 2013, s/p)

É interessante conhecer as situações indutoras dos sentimentos porquê

a identificação de sentimentos e de suas situações indutoras pode ser uma boa base para a discussão com professores, fornecendo-lhes indicadores úteis para que iniciem a reflexão sobre sua prática, levando em consideração a dimensão afetiva, lembrando sempre que as situações indutoras desvelam necessidades de professores e alunos a ser satisfeitas. (ALMEIDA; MAHONEY, 2007, p. 23)

As situações que provocam os sentimentos de incerteza, insatisfação e preocupação no professor, relatada por P1, estão relacionados com: o contexto político, social e de saúde em que o País vivia (e ainda vive) "os rumos da pandemia no Brasil (que se mostrou, 


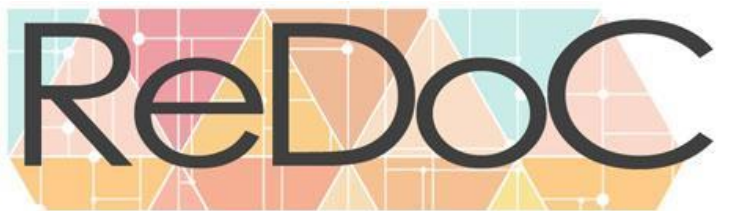

Revista Docência e Cibercultura

posteriormente, incontrolável e irresponsavelmente negligenciada)"; "receios diante da tecnologia e das novas práticas que se colocavam diante de nós" e, ainda, "a situação dos estudantes (principalmente os mais vulneráveis)".

Esse professor identificou nos alunos os sentimentos de ansiedade e impaciência; por um lado, ele relatou como situação indutora o isolamento e a falta da escola e dos amigos, por outro lado, que "eles pareciam conscientes da necessidade do distanciamento e da importância de que o retorno se dê apenas em condições de segurança para todos". Depois de tantos meses, como estarão esses alunos, será que algo mudou? Quais outros sentimentos o professor teria identificado?

Esse professor escreveu, ainda, que teve notícias, por meio de outros professores, de "crianças e adolescentes passando por dificuldades materiais e emocionais nesse período", o que o deixou muito preocupado. Novamente, após sete meses, como estarão estas crianças e suas famílias?

Ademais, identificou que a maioria dos alunos estava preocupados quanto à recuperação do conteúdo do ano em que se instaurou a pandemia. Interessante o movimento do professor de acolhê-los e procurar atender à manifestação do sentimento expresso pelos alunos: "tento tranquilizá-los, dizendo que faremos todo o possível para realizar a recuperação, seja ela contínua ou paralela".

Entretanto, com relação ao futuro escolar, ele ressaltou: “É uma situação inédita para essa geração, então é difícil fazer qualquer prognóstico". Neste mesmo sentido, constatou P5: "O processo de aprendizagem dos alunos está muito aquém do esperado em uma normalidade." Pesquisas internacionais já apontam os prejuízos no aproveitamento das aprendizagens pelos alunos e diversas consequências, como estresse e obesidade, entre outras ${ }^{5}$.

\footnotetext{
${ }^{5}$ Sobre isso, veja: “Adverse consequences of school closures”. Disponível em:<https://en.unesco.org/covid19/educationresponse/consequences\#: :text=High\%20economic $\% 20 \operatorname{costs} \% 3 \mathrm{~A}$ $\% 20$ Working\%20parents,tend $\% 20$ to $\% 20$ negatively\%20impact $\% 20$ productivity.\&text=When $\% 20$ schools $\% 20 \mathrm{cl}$ ose $\% 2 \mathrm{C} \% 20$ many $\% 20$ children,essential\%20to\%20learning\%20and\%20development>. Acesso em: 20 de abr. 2021.;

"Addressing the Consequences of School Closure Due to COVID-19 on Children's Physical and Mental WellBeing”. Disponível em: <https://www.ncbi.nlm.nih.gov/pmc/articles/PMC7461306/pdf/WMH3-9999-na.pdf>. Acesso em: 20 de abr. de 2021.;

"Written evidence submitted by Professor Greta Defeyter Covid-19: Back to School, Rebuilding a Better Future for Children Covid-10 and School 'Closures"'. Disponível em: <https://www.researchgate.net/publication/342069029_Written_evidence_submitted_by_Professor_Greta_Defe yter_Covid-19_Back_to_School_Rebuilding_a_Better_Future_for_All_Children_Covid19_and_School_'Closures'/link/5ee0ca68a6fdcc47689452b4/download>. Acesso em: 20 de abr. de 2021.
} 
Segundo P2, o sentimento de angústia teve como situação indutora a falta de conhecimento sobre como as crianças estão, "o que está acontecendo do outro lado", no caso das aulas remotas, sem presencial. Relacionou também como situação indutora deste sentimento a ausência de informação sobre "como que cada criança está desenvolvendo as lições, se de fato estão ampliando seus conhecimentos". As condições de vida são diferentes de aluno para aluno, tanto econômicas, quanto de disponibilidade para ajudá-los nos estudos; sabe-se que podem ocorrer situações sensíveis, já que há pais analfabetos ou que tenham que trabalhar e, portanto, não tenham disponibilidade de tempo para ajudar as crianças.

A professora P2 levantou também um questionamento sobre o contexto da pandemia e suas consequências: "se a escola pode ser o mais importante para ele, nesse momento, as vezes as condições em casa (falta de alimento, por exemplo) impedem que ele dedique suas energias para o estudo". Qual seria o lugar ocupado pela escola nas diferentes situações de vida atual de cada aluno? Quais são as energias que os alunos têm? Quais são as motivações, ligadas à afetividade, para usá-las?

Esta professora relatou uma mistura de sentimentos, um positivo, satisfação, e outro negativo, tristeza, após a aula online. O primeiro tinha como situação indutora o resultado da "aula desenvolvida e por perceber que os alunos aproveitaram o momento e conseguiram compreender o conteúdo desenvolvido". Ela conseguiu ter uma avaliação da aula e identificou nos alunos o resultado da aprendizagem. Portanto, segundo ela, os alunos do $5^{\circ}$ ano, conseguiram compreender o que ela estava trabalhando, mesmo na situação inusitada de aula online. Crianças com 10 anos, que conseguem acesso à internet e dispositivo adequado, podem ter uma postura que possa aproveitar as aulas mediadas por TDIC.

Todavia, o segundo sentimento estava relacionado com "poucos alunos presentes, comparado as outras" (aulas síncronas). Qual seria a frequência dos alunos e suas rotinas de estudos? O que teria acontecido para que aqueles que participaram de outras aulas não estarem presentes virtualmente? A ausência do aluno impede que os professores atuem no processo de aprendizagem e mesmo no acolhimento.

É importante ressaltar que os cinco professores relataram que, em média, participam dos encontros síncronos $15 \%$ da turma, variando às vezes um pouco mais ou menos (esporadicamente $50 \%$ da turma). As barreiras para ausência podem ser diversas: desde falta de infraestrutura até motivação. Seriam necessárias novas pesquisas sobre esta temática para levantar e compreender os motivos, mas é importante notar que a gestão da escola faz um trabalho de busca ativa pelos alunos. 
Com relação a identificar sentimentos nos alunos, P2 expressou: "Muito difícil responder essa questão". Provavelmente por conta do contexto de aulas mediadas pelas TDIC e pouco contato com os alunos. Ela atribuiu a questão do apoio ou não da família para relatar a participação e assiduidade ou não dos alunos. Aqueles alunos que recebem o apoio familiar, percebeu, "aproveitam as atividades, participam e demonstram bons avanços". Entretanto, naqueles que ela notou a ausência de respaldo familiar, houve o prejuízo do processo de aprendizagem: "não são assíduos nas lições, participam esporadicamente".

Para P3, os sentimentos de angústia e ansiedade são com relação ao período anterior ao início das aulas virtuais, e explica: "por não saber previamente quando seria, de que forma seria e como alcançaria todas as crianças, tendo em vista que na rede pública, em que trabalho muitos não têm acesso à internet e ou ao computador", demonstra preocupação com as condições de infraestrutura dos alunos, importante para o processo de ensino aprendizagem.

Ela oscila entre ser afetada por sentimentos positivos e negativos, ora triste, ora feliz. $\mathrm{O}$ sentimento de triste teve como situação indutora os desafios presentes na aula a distância pois, segundo ela, "uma aula poderia ser explorada de uma maneira mais significativa e detalhada, mas a distância não possibilita", lembrando que esta professora leciona há 11 anos. O mesmo sentimento está também relacionado com pouco retorno e acesso dos alunos: "ou por ver que poucos são os retornos e acessos destes estudantes". Destaca-se da fala desta professora a limitação que ocorre nas aulas online, pois algumas atividades não são possíveis de serem realizadas.

O sentimento positivo para ela estava relacionado a dois aspectos: a presença dos alunos em um clima de alegria, "quando termino uma live e vejo quantos estiveram presentes e que a distância não impediu a alegria e participação"; e quando ela recebe um retorno positivo sobre um recurso produzido por ela e que tenha colaborado no processo de aprendizagem dos alunos "bem como quando eu faço um vídeo para auxiliar a criança que disse não ter compreendido a proposta e depois recebo a informação de que o vídeo ajudou a atender e fazer de forma adequada a atividade."

É oportuno diferenciar o tipo de interação que possibilita uma aula síncrona daquela de uma live. O propósito de cada situação é diverso: a primeira, em sua maioria, tem um número de pessoas mais adequado para que se tenha uma interação com vídeo e áudio, incluindo o chat. Já uma live é na direção de broadcasting, um falando para muitos e aqueles que assistem (mais passivamente) só podem intervir por meio de chat escrito. Outra perspectiva é o modismo do momento, pois lives começaram a ser costumeiras na pandemia. 


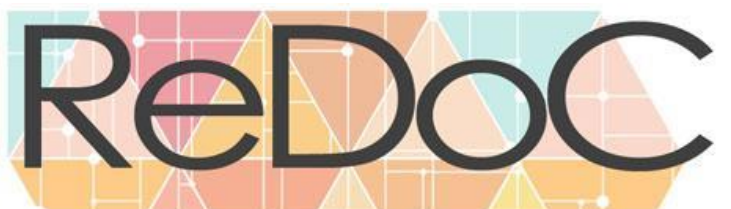

\section{Revista Docência e Cibercultura}

Percebe-se que há uma relação direta com o processo de aprendizagem dos alunos e o sentimento de alegria desta professora, pois ela é um elemento privilegiado do meio do aluno (ALMEIDA, 2002).

Como descreveu Tassoni (2013),

é fundamental, no contexto escolar, o olhar atento do professor, sua escuta, suas intervenções, traduzindo as expectativas dos alunos, dúvidas e necessidades. A escola é um local de interações sociais intensas e variadas e é neste espaço que os alunos desenvolvem suas potencialidades, transformam ou concretizam a imagem que trazem de si mesmos. Por isso, as confirmações a respeito do próprio trabalho, as respostas às suas dúvidas, as intervenções que promovem compreensão são ações pedagógicas de natureza também afetiva. (TASSONI, 2013, s/p.)

O sentimento de muita ansiedade foi relatado duas vezes por P4. E estava relacionado com a situação de novidade: "com as mudanças e com as necessidades de adaptação. Estamos acostumados com um modelo e rapidamente, sem tempo de adaptação, tivemos que mudar para outro", condições inesperadas e sem tempo de adaptação e preparação. Esta professora tem 36 anos e leciona há 10 anos. Provavelmente suas experiências com uso de TDIC e integração ao currículo, até o momento não tinham atingido um grau de conforto e, por isso, tenha ocasionado o sentimento de muita ansiedade.

Completou seu depoimento ainda com o estado emocional de que as aulas remotas são "bem complicadas para mim". Ou seja, ela foi afetada de forma negativa pela situação. Realmente, precisou despender muita energia para esta nova rotina. Professores relatam trabalhar mais e estarem cansados nesta situação de aulas remotas. Todavia, não se acomodou diante do desafio e contou: "a gente vai se adaptando e vai fazendo o que é possível no momento". Vemos, assim, como uma das grandes capacidades do ser humano é de se adaptar.

Observamos o quanto a ansiedade com o estado emocional da $\mathrm{P} 4$ estava presente de forma mais permanente. Pois, mesmo quando perguntada sobre seus sentimentos após a aula, relata "Ansiedade em geral". Ela voltou a comentar sobre a expectativa de como seriam as aulas online, ressalta a importância de ter o planejamento e segui-lo. Mesmo neste estado emocional procura maneiras de "conduzir de forma tranquila, as aulas online, as lives". As ações para chegar a tranquilidade parece ser a segurança no planejamento, já pensado previamente nas atividades e objetivos, estratégias das aulas, e o apoio das colegas professoras. Contou que fazia as atividades síncronas com as três turmas de quintos anos juntos e de forma colaborativa: "uma lê a outra questiona, vamos administrando esta gestão da aula online". Corrobora, assim, com os estudos apresentados em Arruda (2012), que avalia que, para utilizar as tecnologias digitais integradas ao currículo, é importante ter um bom planejamento de aula registrado. 


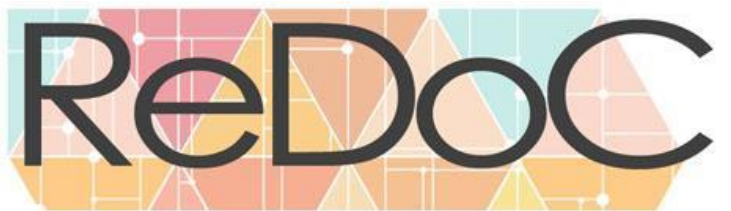

Revista Docência e Cibercultura

Pensativa foi o sentimento que P5 expressou antes de começar a aula online; teve como situação indutora a expectativa de como estaria a disposição dos alunos para a aula síncrona: "se estariam entediados, cansados". Relatou estar surpresa com relação aos sentimentos que ela constatou neles "estavam felizes mostrando seus animais de estimação. Ressalto que em média tenho nas lives 10 alunos".

A escola entrou dentro das casas dos alunos, e deu a possibilidade de mostrar seus "animais de estimação" criando uma atmosfera familiar. Neste caso, não apareceu uma polêmica que tem ocorrido sobre os alunos deixarem suas câmeras abertas ou fechadas. Neste caso específico, para conseguir ver os animais, é preciso ter câmeras ligadas.

A P5 frisou a questão da pouca quantidade de alunos participando das aulas síncronas, que nomeia como live. As consequências da ausência das escolas presenciais para crianças são grandes e impactam negativamente nos seus desenvolvimentos. Assim como a P4, ela nomeia a aula síncrona como live, necessitando diferenciar este conceito.

Na contramão do isolamento social, Wallon (1975) nos apresenta a necessidade do outro, ao definir o ser humano como essencialmente social, "É-o geneticamente" (p. 156). Isso porque, desde que nascemos, existe uma necessidade íntima de convívio com o outro, até mesmo para o bebê sobreviver. Ao chorar, ele mobiliza a mãe para alimentá-lo e, assim, poder crescer e se desenvolver. Posteriormente, a importância do outro continua impactando na construção da identidade de cada pessoa.

Quanto ao sentimento identificado pela P5 após a aula, indicou o senso de responsabilidade "de estar tentando fazer minha parte no contexto atual" e, ao mesmo tempo, ela aborda a corresponsabilidade neste cenário, "afinal não somos os únicos responsáveis".

Os pares dialéticos ensino-aprendizagem, professor-aluno, são os amparos para a necessidade de abordarmos também os sentimentos identificados por estes professores em seus alunos. Mesmo porque na relação intrapessoal e no desenvolvimento as necessidades presentes nos aspectos motores e afetivos dos alunos também estão presentes e devem ser considerados pelos professores.

Não basta ter acesso ao computador conectado à internet. É preciso, além de ter acesso aos meios digitais e sua infraestrutura, vivenciar a cultura digital com autoria criadora e cidadã. Saber buscar e tratar a informação em rede, transformar informação em conhecimento, comunicar-se em rede, produzir textos em várias linguagens e suportes são saberes fundamentais para integração e autoria na cibercultura. Esses saberes da cibercultura são fundamentais para o exercício da docência online. (SANTOS, 2019, p.92) 
Isolados em confinamento nas suas casas, como os professores podem atender às necessidades motoras, corpóreas dos alunos? E as suas próprias? Muitos professores e alunos, que têm condições de acesso aos dispositivos e internet, passam muitas horas sentados no computador, ou/e celular. É importante o deslocamento no espaço e atender às necessidades motoras, que repercutem nos aspectos cognitivos e afetivos, respeitando a integridade proposta por Wallon. Apontamos a necessidade de pesquisas futuras sobre os impactos no aspecto motor de alunos e professores.

\section{b. Dimensão afetiva prazer}

A intencionalidade pedagógica do professor é também motivada pela sua dimensão afetiva de prazer e desprazer. Envolve questões relacionadas aos currículos, à interação com os alunos e ao próprio processo ensino-aprendizagem, meios e estratégias presentes no ato de ensinar, bem como planejamentos e avaliações. Os alunos, por sua vez, também completos motor-afetivocognitivo têm suas necessidades, motivos e valores presentes nas interações pedagógicas escolares.

Para Mahoney e Almeida (2004),

A observação apura o olhar, não só do professor em relação ao seu aluno, mas em relação a si próprio: na medida em que percebe o desenvolvimento do aluno, o seu jeito na sala de aula, o seu interesse/desinteresse por certos tópicos, o ritmo do grupo $\mathrm{com} / \mathrm{sem}$ sua presença, o mal-estar/bem-estar do aluno em certos momentos na aula, o professor está revendo seu próprio papel de professor" (MAHONEY; ALMEIDA, 2004, p.135)

A seguir organizamos um quadro síntese sobre as atividades de que os professores mais gostaram e suas explicações:

Quadro 2. Percepção sobre atividades de que mais gostaram

\begin{tabular}{|c|c|c|c|c|}
\hline $\begin{array}{c}\text { P1 } \\
\left(6 \text { e }^{\left.7^{\circ} \text { anos }\right)}\right.\end{array}$ & P2 (3ªno) & P3 (4ºno) & P4 (5'ano) & P5 (4ºno) \\
\hline $\begin{array}{l}\text { Atividade } \\
\text { interdisciplinar com } \\
\text { o tema da Educação } \\
\text { Antirracista, } \\
\text { "Mulheres negras e o } \\
\text { trabalho", } \\
\text { conseguiram }\end{array}$ & $\begin{array}{l}\text { Aulas síncronas pelo } \\
\text { Google Meet usando } \\
\text { a ferramenta } \\
\text { Jamboard. } \\
\text { Movimentação das } \\
\text { imagens e a } \\
\text { possibilidade de } \\
\text { escrever, faz com }\end{array}$ & $\begin{array}{l}\text { Encontros virtuais nos } \\
\text { quais faço desafios para } \\
\text { que as crianças } \\
\text { respondam. } \\
\text { Português e } \\
\text { Matemática, todas de } \\
\text { forma simples, mas }\end{array}$ & $\begin{array}{l}\text { Em geral eu gosto } \\
\text { bastante de todas. } \\
\text { Produz material } \\
\text { complementar e de } \\
\text { apoio ou material }\end{array}$ & $\begin{array}{l}\text { Diário da } \\
\text { quarentena que } \\
\text { estou trabalhando } \\
\text { desde abril. As } \\
\text { atividades do } \\
\text { projeto envolvem } \\
\text { trabalhar a } \\
\text { biografia de }\end{array}$ \\
\hline
\end{tabular}




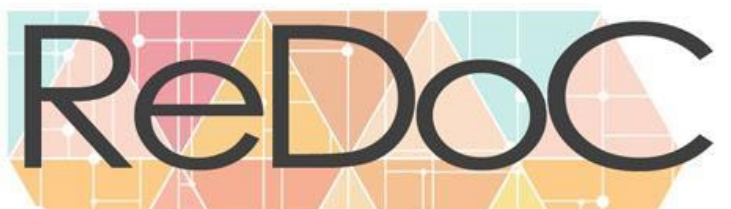

Revista Docência e Cibercultura

\begin{tabular}{|c|c|c|c|c|}
\hline $\begin{array}{l}\text { enxergar as relações } \\
\text { racistas e machistas } \\
\text { nesse contexto. }\end{array}$ & $\begin{array}{l}\text { que ele sirva de } \\
\text { lousa virtual. }\end{array}$ & $\begin{array}{l}\text { lúdica e contemplando } \\
\text { o trabalho que foi } \\
\text { realizado até o } \\
\text { momento, com o livro } \\
\text { que estamos } \\
\text { trabalhando. }\end{array}$ & $\begin{array}{l}\text { extra. Um dia na } \\
\text { semana reforço. }\end{array}$ & $\begin{array}{l}\text { pessoalidades } \\
\text { negras e indígenas } \\
\text { - a ideia é finalizar } \\
\text { o projeto com um } \\
\text { lap boock. }\end{array}$ \\
\hline $\begin{array}{l}\text { Resposta muito } \\
\text { interessante dos } \\
\text { estudantes, que } \\
\text { conseguiram, em sua } \\
\text { maioria, enxergar as } \\
\text { relações racistas e } \\
\text { machistas nesse } \\
\text { contexto. }\end{array}$ & $\begin{array}{l}\text { Os alunos gostam } \\
\text { muito dessas aulas, } \\
\text { eles demonstram } \\
\text { interesse e } \\
\text { participam } \\
\text { efetivamente. }\end{array}$ & $\begin{array}{l}\text { Dão um afago no } \\
\text { coração, pois são como } \\
\text { se estivéssemos na sala } \\
\text { de aula } \\
\text { presencialmente, pois } \\
\text { na medida do possível } \\
\text { ocorrem conversas e } \\
\text { trocas, além disso posso } \\
\underline{\text { ver o rostinho deles e }} \\
\text { ver o prazer deles em } \\
\text { realizar estas } \\
\text { atividades/esses } \\
\text { desafios, ou seja, tenho } \\
\text { o feedback rápido e o } \\
\text { posicionamento se eles } \\
\text { estão gostando ou não } \\
\text { destes desafios e da } \\
\text { aula. }\end{array}$ & $\begin{array}{l}\text { Coisas que a gente } \\
\text { acha que a criança } \\
\text { vai ter muita } \\
\text { dificuldade de } \\
\text { compreender. Ou } \\
\text { uma atividade que } \\
\text { achamos que está } \\
\text { muito tranquilo, } \\
\text { muito fácil. }\end{array}$ & $\begin{array}{l}\text { Absoluta surpresa } \\
\text { SME colocou o } \\
\text { Dário de Miryam } \\
\text { no Trilhas 2, isso } \\
\text { enriqueceu ainda } \\
\text { mais nosso } \\
\text { trabalho. }\end{array}$ \\
\hline
\end{tabular}

Fonte: autoras.

As professoras $\mathrm{P} 2$ e P3 destacaram como atividade de que mais gostam o momento síncrono com os alunos. P2 comentou sobre a utilização de um recurso (jamboard) que permite ações como se fosse uma "lousa virtual", o que possibilitaria escrever e os alunos verem a movimentação de poliedros, avaliando que "ver as imagens e interagir é imprescindível para este conteúdo". Ela relata que já consegue diferenciar o momento mais adequado para a utilização desse recurso: "uso dele é mais efetivo nas aulas síncronas". O termômetro para ela foi a satisfação demonstrada pelos alunos: "Os alunos gostam muito dessas aulas, eles demonstram interesse e participam efetivamente". O que podemos perceber que o gostar do professor se relaciona diretamente ao gostar dos alunos e pode repercutir positivamente para $o$ processo de aprendizagem.

Segundo Mahoney e Almeida (2004), a "mediação do professor será tanto mais eficaz quanto maior for o número de linguagens de que dispõe" (p. 127). Daí a importância do letramento digital de professores para que possam utilizar em suas aulas diversas linguagens midiáticas e recursos que possam potencializar o processo de aprendizagem e permitir que os alunos pensem e reflitam de outras maneiras.

A professora P3 relatou que faz desafios lúdicos de matemática e português nos encontros virtuais e que estes momentos, "dão um afago no coração, pois são como se estivéssemos na 


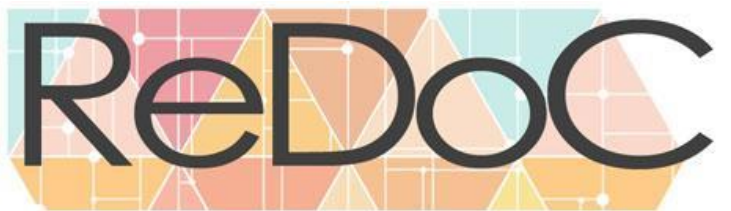

Revista Docência e Cibercultura

sala de aula presencialmente, pois na medida do possível ocorrem conversas e trocas, além disso posso ver o rostinho deles e ver o prazer deles em realizar estas atividades/esses desafios, ou seja, tenho o feedback rápido e o posicionamento se eles estão gostando ou não destes desafios e da aula."

Na situação das aulas remotas, o momento síncrono possibilita a visualização da reação corpórea dos alunos, revelando as manifestações emocionais positivas ou negativas quando estão com as câmeras abertas. É no rosto que vê a reação de prazer, conforme explorado na pesquisa em Arruda (2005).

A pesquisa realizada por Castro e Queiroz (2020) corrobora com esta professora:

Em relação às dificuldades psicológicas os docentes afirmam que a maior delas está em não ver as pessoas, não ter o contato visual, se sentirem falando com a máquina, fazendo as aulas sem interação humana. Isso torna a atividade docente cansativa, frustrante e ineficiente. (CASTRO E QUEIROZ, 2020, p. 13)

A professora (P3) ressalta também a importância do diálogo e trocas, tão caros à educação (FREIRE, 1998). Assim também, os desafios variados propostos pela professora são importantes no desenvolvimento das crianças:

Quanto maior a variedade de oportunidades que a criança tem à sua disposição para exercitar as funções que amadurecem a cada estágio, melhor o desenvolvimento de suas aptidões para enfrentar as exigências do meio. Daí a importância de a escola oferecer variedade de situações. (MAHONEY; ALMEIDA, 2004, p.22)

Já P4 comentou gostar de todas as atividades, citando algumas: ajudar uma colega na produção de formulários, procurar vídeos no youtube para complementar as atividades, livros, gravar áudio, fazer live. Pontuou estar atenta à aprendizagem dos alunos: quanto aos conteúdos que as crianças terão dificuldades para compreender, ela procura produzir material com maiores explicações de apoio e complementar, por outro lado, para aqueles conteúdos muito fáceis, desenvolve materiais extras.

A professora está aprendendo com sua colega e na situação de aulas mediadas pela TDIC, como escreveu Santos (2019) "Muitos docentes online formam-se no contexto das suas primeiras experiências profissionais, aprendendo com seus pares e em sua relação com seus estudantes." (p.93), além disso,

Para que a diversidade de linguagens, produções e experiências de vida sejam de fato contempladas de forma multirrefencializada, nos e pelos espaços de aprendizagem, os saberes precisam ganhar visibilidade e mobilidade coletiva, ou seja, os sujeitos do conhecimento precisam ter sua alteridade reconhecida, sentindo-se implicados numa produção coletiva, dinâmica e interativa que rompa com os limites do tempo e do espaço geográfico. (SANTOS, 2019, p.82) 
É interessante que mesmo em situação incomum, mantiveram a recuperação contínua, para aqueles que podem participar, como falou P4: "Às sextas-feiras, estamos propondo uma atividade de recuperação contínua, que são atividades que fazíamos na sala de aula, como resolução de problemas, leitura e compreensão de textos."

Os professores P1 e P5 apresentaram atividades pontuais: "uma atividade interdisciplinar com o tema da Educação Antirracista" e "diário da quarentena que estou trabalhando desde abril. As atividades do projeto envolvem trabalhar a biografia de pessoalidades negras e indígenas".

É interessante ele destacar uma atividade em que estavam presentes três áreas de conhecimentos: História, Geografia e Artes, o que aponta para uma abordagem menos fragmentária. Relatou ele: "Produzimos um material com texto, estatísticas e música e oferecemos para os estudantes". Com relação à aprendizagem dos alunos, concluiu: "tive uma resposta muito interessante dos estudantes, que conseguiram, em sua maioria, enxergar as relações racistas e machistas nesse contexto".

A professora P5 destacou um sentimento de surpresa com relação ao caderno do aluno "trilhas 2": "Para minha absoluta surpresa SME colocou o Dário de Miryam no Trilhas 2, isso enriqueceu ainda mais nosso trabalho". Constata-se que o trabalho desta professora estava articulado com o currículo da cidade, proposta da SMESP.

Estes professores parecem atentos às manifestações de seus alunos. A unidade e movimento de reciprocidade do par dialético ensino-aprendizagem requer esta postura deles. Seria interessante perguntar para os alunos sobre quais atividades de que eles mais gostam e por quê, e de quais eles menos gostam e por quais razões, assim forneceriam mais elementos de ancoragem para as atividades propostas pelos professores na situação de aulas mediadas pelas TDIC.

Ambos, professor e aluno, participam de vários meios, entre eles a escola:

- a escola é um meio fundamental para o desenvolvimento do professor e do aluno, ao dar oportunidades de participação em diferentes grupos;

- nesse meio, professor e aluno são afetados um pelo outro, e, ambos, pelo contexto onde estão inseridos;

- a não satisfação das necessidades afetivas, cognitivas e motoras prejudica a ambos, e isso afeta diretamente o processo ensino-aprendizagem:

— no aluno, pode gerar dificuldades de aprendizagem;

- no professor, gera insatisfação, descompromisso, apatia, podendo chegar ao burnout, prejudicando sua atividade. (MAHONEY; ALMEIDA, 2005, p.13) 
Quanto é possível atender às necessidades motoras de alunos e professores, neste contexto em que o isolamento social em suas casas foi imposto? Quais são estes grupos formados no contexto das aulas híbridas? Percebe-se pelos relatos dos cinco professores que eles estão afetados pelo contexto de aulas mediadas pelas TDIC, em que estão inseridos.

Retomando a ideia de Wallon (1936), nós modificamos o meio físico, obrigando às transformações sociais e assim, transformamos a nós mesmos. Professores, diante do enorme desafio imposto pela pandemia, são afetados e procuram perceber (na medida do possível) os sentimentos de seus alunos, encontram caminhos diversos e experimentam uso destes recursos tecnológicos no processo ensino-aprendizagem. Segundo Prandini (2020), "É na escola que, através de conflitos e oposições, o professor se forma ao ensinar seus os alunos e, assim, exerce seu potencial transformador sobre o meio que o constitui." (PRANDINI, 2020, p. 108).

A professora P5 manifestou sua percepção da escola quando relatou: "Às vezes penso que a escola dormiu no século XIX e acordou no século XXI". Esta fala da professora parece demonstrar que a escola está atrasada em relação à sociedade. A função social da escola está relacionada à transmissão dos conhecimentos acumulados pela humanidade, mas também de preparar e apontar para o futuro disseminando novos conhecimentos, novas descobertas científicas, bem como as questões relacionadas com as TDIC. A escola está imersa na sociedade, sofre influências desta, mas também a influencia. Sendo assim, a escola é um espaço de síntese ligada ao passado, ao presente e também ao futuro.

\section{c. Dimensão afetiva desprazer}

No processo ensino-aprendizagem é igualmente importante reconhecer as atividades de que os professores menos gostaram para identificar os motivos e não serem empecilhos no desenvolvimento dos alunos, mas sim vistos como desafios a serem superados.

Os relatos dos professores foram organizados no quadro a seguir:

Quadro 3. Percepção sobre atividades que menos gostaram

\begin{tabular}{|l|l|l|l|l|}
\hline \multicolumn{1}{|c|}{$\mathbf{P 1}\left(\mathbf{6}^{\mathbf{0}} \mathbf{e} \mathbf{7}^{\mathbf{0}}\right)$} & \multicolumn{1}{|c|}{$\mathbf{P 2}\left(\mathbf{3}^{\mathbf{o}}\right)$} & \multicolumn{1}{|c|}{$\mathbf{P 3}\left(\mathbf{4}^{\mathbf{0}}\right)$} & $\mathbf{P 4}\left(\mathbf{5}^{\mathbf{0}}\right)$ & $\left.\mathbf{P 5} \mathbf{4}^{\mathbf{0}}\right)$ \\
\hline $\begin{array}{l}\text { Mesmo projeto } \\
\text { interdisciplinar, } \\
\text { poucos se } \\
\text { engajaram na } \\
\text { proposta, muito } \\
\text { aquém do esperado }\end{array}$ & $\begin{array}{l}\text { Roteiros “frios" e } \\
\text { o retorno dos } \\
\text { alunos era menor. }\end{array}$ & $\begin{array}{l}\text { As crianças não } \\
\text { tiveram a } \\
\text { oportunidade de } \\
\text { vivenciá-la na } \\
\text { prática e pedir que } \\
\text { fizesse uma } \\
\text { observação em casa }\end{array}$ & $\begin{array}{l}\text { As crianças } \\
\text { tiveram muita } \\
\text { dificuldade de } \\
\text { responder, não } \\
\text { conseguimos } \\
\text { corrigir. Essa } \\
\text { devolutiva é }\end{array}$ & \\
\hline
\end{tabular}




\begin{tabular}{|c|c|c|c|c|}
\hline $\begin{array}{l}\text { e do que foi feito na } \\
\text { semana anterior. }\end{array}$ & & $\begin{array}{l}\text { poderia correr um } \\
\text { risco por conta da } \\
\text { pandemia, sendo } \\
\text { que estamos em } \\
\text { isolamento e as } \\
\text { crianças podem } \\
\text { morar em casa sem } \\
\text { quintal ou } \\
\text { apartamento. Não } \\
\text { achei significativo } \\
\text { não gostei de dar } \\
\text { esta aula. muitas das } \\
\text { crianças não } \\
\text { conseguiram } \\
\text { realizar de forma } \\
\text { adequada. }\end{array}$ & $\begin{array}{l}\text { muito } \\
\text { complicada. }\end{array}$ & \\
\hline Produção artística. & $\begin{array}{l}\text { Roteiros onde eu } \\
\text { só escrevia as } \\
\text { orientações e } \\
\text { apresentava as } \\
\text { explicações e } \\
\text { exercícios. }\end{array}$ & $\begin{array}{l}\text { Movimento } \\
\text { aparente do sol, e } \\
\text { uma atividade que } \\
\text { que solicitava a } \\
\text { classificação do dia, } \\
\text { tarde e noite. }\end{array}$ & $\begin{array}{l}\text { Usar o recurso } \\
\text { do word. }\end{array}$ & $\begin{array}{l}\text { Atividades do } \\
\text { trilhas - } 1 \text { que } \\
\text { trabalharam a } \\
\text { cadeia produtiva de } \\
\text { alguns produtos } \\
\text { como o leite, } \\
\text { desconsiderando o } \\
\text { agronegócio e sua } \\
\text { relação coma } \\
\text { agricultura } \\
\text { familiar. }\end{array}$ \\
\hline
\end{tabular}

Fonte: autoras.

As atividades relatadas pelos professores foram diversas: produção artística (P1), roteiros sem maior interação "onde eu só escrevia as orientações e apresentava as explicações e exercícios" (P2), movimento aparente do sol, e uma atividade que solicitava a classificação do dia, tarde e noite (P3), usar o recurso do word (P4) e atividades do "Trilhas - Caderno 1" que trabalharam a cadeia produtiva de alguns produtos como o leite, desconsiderando o agronegócio e sua relação coma agricultura familiar (P5).

As explicações e relações apresentadas também são diversas. Mas, algumas focaram na relação com a reação dos alunos:

- "poucos se engajaram na proposta, muito aquém do esperado" (P1), mesmo sendo a mesma atividade que ele relatou ter mais gostado na semana anterior.

- "retorno dos alunos era menor" (P2).

- "as crianças não tiveram a oportunidade de vivenciá-la na prática. Muitas das crianças não conseguiram realizar de forma adequada" (P3). 


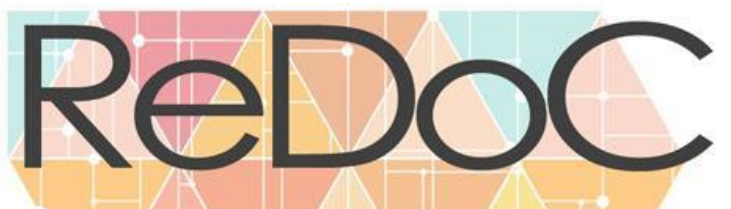

Revista Docência e Cibercultura

- "as crianças tiveram muita dificuldade de responder no próprio documento, não conseguiram utilizar" e também "quando as crianças enviam as fotos das atividades, muitas vezes as fotos são pouco legíveis, ou ilegíveis, não conseguimos corrigir” (P4).

A professora $\mathrm{P} 4$ relaciona atividades de que menos gostam com dificuldades de utilização de ferramentas pelos alunos para fazerem atividades nesse contex to remoto. Percebe-se que os alunos, que nasceram imersos na cultura digital e vivenciam a cibercultura nos seus cotidianos, precisam também aprender a lidar com recursos das TDIC. Muitas vezes sabem utilizá-las para entretenimento em suas redes sociais, mas não como recurso para estudar e aprender. Por não receber adequadamente a atividade dos alunos, a professora também não consegue fazer suas intervenções e mediação na construção do conhecimento: "Essa devolutiva é muito complicado, a correção de atividades".

A aprendizagem é, além dos automatismos naturais, mais um recurso de que a criança dispõe para responder às exigências de adaptação ao meio humano e físico que a rodeia e constituir-se como indivíduo. [...] Aprender é transformar-se na relação com o outro. (MAHONEY; ALMEIDA, 2004, p. 19)

Diante dessa dificuldade dos alunos, que implica em dificuldades no processo de ensinoaprendizagem, por experimentações, a professora (P4) já apontou um caminho: "Então o formulário tem ajudado um pouco nisso, nele já conseguimos fazer uma correção, dá um feedback, porque nas imagens, algumas imagens das atividades nós conseguimos sim, colocar um comentário, dar um feedback, fazer uma correção".

A professora P3 também relatou caminhos que procurou seguir diante destes desafios: "Hoje procuro sempre colocar algo que aproxime o estudante, seja um vídeo, um áudio, um jogo, entre outros" (P2). Ela comentou sobre seu percurso formativo: "No início, quando eu não tinha conhecimento de possíveis ferramentas, os roteiros onde eu só escrevia as orientações e apresentava as explicações e exercícios, me pareciam frios". Ela relaciona o pouco retorno dos alunos com pouca interação, e também links e atividades que aproximem os estudantes.

Já a professora P3 abordou a questão da maneira como a atividade foi trabalhada no contexto da pandemia de aula remota, sem ser presencial e ausência de uma vivência com observação direta pelos alunos - "Foi muito complicada". Não foi uma atividade significativa e não agregou conhecimento, segundo ela. Completou dizendo: "As sombras não estavam de acordo, não facilitava a visualização da criança e a classificação da criança. Tendo em vista que estas aulas presencialmente, seriam realizadas de forma diferente com dinâmicas". Concluiu dizendo que "muitas das crianças não conseguiram realizar de forma adequada". Será que outros 
recursos tecnológicos disponíveis na internet não permitiriam trabalhar de forma significativa este conceito?

Os currículos em desenvolvimento trabalhados pelos professores e gestores também precisaram ser revistos. Segundo Menezes e Francisco (2020), que fizeram uma revisão da literatura referente aos impactos sociais e afetivos sobre o processo ensino-aprendizagem gerados pela pandemia por COVID-19, "os professores precisam de apoio das instituições de ensino para se manterem saudáveis e amparados durante a pandemia. Essa adaptação brusca e obrigatória pode afetar negativamente a experiência docente" (MENEZES E FRANCISCO, 2020, p. 1007).

\section{AFAGO NO CORAÇÃO E TRISTEZA}

\section{Afago no coração e tristeza}

Os sentimentos relatados pelos professores no contexto de aulas mediadas por TDIC durante a pandemia e suas situações indutoras revelaram que foram afetados ora por sentimentos positivos ora negativos. É importante destacar a necessidade de atender às manifestações dos aspectos afetivos, cognitivos e motores de alunos e professores, mesmo no contexto inesperado e instável da educação atual.

Percebe-se que os sentimentos negativos não paralisaram estes cinco professores, que parecem se mobilizar para aprender a lidar com as situações e buscar soluções para o processo ensinoaprendizagem. Observamos nas atividades relatadas a intencionalidade pedagógica dos professores para que sejam atividades significativas e possam compreender os conteúdos, mesmo nas aulas remotas.

As principais situações indutoras estão relacionadas com questões da inserção das TDIC nas suas práticas pedagógicas, a relação e saber como os alunos estariam e acompanhar o processo de aprendizagem deles. Os professores identificam sentimentos diversos nos alunos, tais como: preocupados, felizes, ansiosos e impacientes. Eles identificam situações diversas nos alunos, na ordem: se conseguiriam recuperar o conteúdo daquele ano, poderem mostrar seus animais de estimação, estarem isolados em suas casas, sem escola e os amigos. Uma das professoras percebe nitidamente que o apoio da família faz a diferença para o aluno participar ou não das aulas remotas. 
Ansiedade e angústia são sentimentos destacados e tiveram como situação indutora a novidade e expectativa das aulas síncronas e assíncronas impostas pela situação da pandemia. O que requer formação dos professores durante sua atuação, até para distinguir aula síncrona de uma live, dentre outras possibilidades.

Feliz e satisfação foram destacados por duas professoras. Uma delas por perceber que a distância não impediu a participação dos alunos na aula síncrona e alegria dos alunos e dela própria, bem como outra professora destacou os alunos aproveitarem o momento e conseguiram compreender o conteúdo.

O sentimento de tristeza foi descrito por duas professoras e tiveram como situações indutoras a pouca presença de alunos na aula síncrona, pouco retorno e acesso dos alunos e, para outra professora, as impossibilidades impostas pela aula a distância que não permite explorar de maneira mais significativa e detalhada os conteúdos. Aqui apontamos a necessidade de formação de professores para, de forma crítica e criativa, lidar com a integração das TDIC aos currículos. Entretanto, as aulas a distância têm suas limitações.

O sentimento de tranquilidade estava relacionado à gestão da aula síncrona e seguir o planejamento e fazer a gestão juntamente com outras colegas, que podem se apoiar. Das atividades de que mais gostaram de trabalhar com os alunos, destacamos: atividades síncronas com desafios de forma lúdica e as próprias aulas síncronas, pois para uma professora esses momentos oferecem um "afago no coração" e que ela pode ver o "rostinho deles"; nesses encontros ocorrem conversas e trocas, pode identificar o interesse dos alunos e participam efetivamente. Os momentos síncronos com câmeras abertas, permitem ao professor visualizar a reação corpórea - emoção, segundo Wallon - das crianças, ao nomeá-las os professores identificam sentimentos e podem atendê-los e balizar sua prática pedagógica. Desta forma, possibilita aos professores compreenderem as dificuldades de aprendizagem, o interesse e desinteresse dos alunos (par dialético aluno-professor).

Uma das professoras, atenta ao processo de aprendizagem e sua atuação para os alunos desenvolverem-se, relatou que, naqueles conteúdos em que identifica terem dificuldade, ela produz materiais que permitem maiores explicações; para aquelas atividades fáceis do "trilhas", ela produz materiais extras para ampliar os conhecimentos.

Com relação às atividades de que os professores menos gostaram, três tinham relações com as TDIC, seja fazer roteiros "frios" com pouco retorno dos alunos e depois de conhecer melhor os recursos conseguir inserir links que tivessem mais interesse para os alunos. Assim, anexar arquivos e trabalhar no word revelaram que as crianças não conseguiram e a professora não pode dar devolutiva. E, por fim, outra professora destacou a impossibilidade de vivenciar uma 


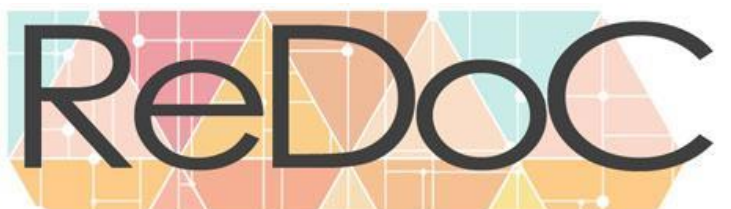

Revista Docência e Cibercultura

atividade pelos alunos, pois a situação "distância" não permitiu que a atividade fosse bem realizada, assim, para ela, não foi significativa.

\section{CONSIDERAÇÕES FINAIS}

Os desafios de integração das TDIC no processo ensino-aprendizagem impostos pela pandemia são diversos e complexos. Constatou-se, com base na teoria de Wallon, que a afetividade é um importante componente presente no processo ensino-aprendizagem. As situações indutoras podem fornecer importantes pistas para professores e gestores atuarem nas escolas, em situação inusitada de imposição da inserção das TDIC em suas práticas pedagógicas.

As aulas síncronas, alunos com câmeras abertas, professora fazendo desafios lúdicos de matemática e língua portuguesa mostraram ser um caminho para uma qualidade na relação e vínculo entre professoras e alunos (felizes e alegres). A parceria entre professores na gestão destas aulas síncronas também se mostrou outro percurso produtivo, proporcionando tranquilidade para a professora na condução. Portanto, os professores são componentes privilegiados do meio dos alunos, nas escolas, na medida em que proporciona desafios, contato com a cultura e oportunidades de aprender e desenvolverem-se.

Constata-se a necessidade de intensificar a formação dos professores para que eles conheçam de forma criteriosa as características, potenciais e limitações das TDIC e, assim, possam utilizálas de forma criativa na produção do conhecimento.

A falta de frequência dos alunos nas aulas remotas foi um aspecto que impactou os professores da investigação. Um estudo complementar é necessário para conhecer os motivos de uma significativa parcela de estudantes faltarem às aulas. Temos como hipóteses a desmotivação pelo cenário de pandemia e barreiras tecnológicas, tais como dificuldade de acesso à internet, bem como falta de equipamentos necessários para tal.

Os sentimentos e emoções vivenciados pelos professores neste estudo apresentam-se como elementos relevantes os quais justificam a iniciativa de novas pesquisas no sentido de: conhecer sobre o apoio familiar dados aos estudantes nas aulas remotas; encontrar situações estratégicas e metodológicas para reinventar o ensino online; e, possivelmente desenvolver propostas de ensino híbrido para o futuro. 


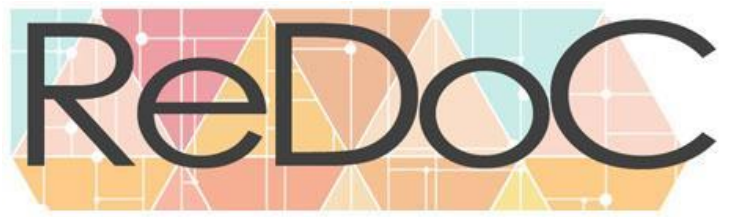

Revista Docência e Cibercultura

\section{Referências}

ALMEIDA, Maria E. B. de; SILVA, M. da G. M. da. Currículo, tecnologia e cultura digital: espaços e tempos de web currículo. Revista e-curriculum, São Paulo, v. 7 n. 1, abr. 2011. Disponível em: 〈https://revistas.pucsp.br/curriculum/article/view/5676>. Acesso em: 10 jan. 2021.

ALMEIDA, Fernando J.; FRANCO, Mônica G. Tecnologias para a educação e políticas curriculares de Estado. In: CETIC.BR. TIC - educação 2013. São Paulo: 2014, p. 41-52.

ALMEIDA, Laurinda R.; MAHONEY, Abigail (Orgs.). Afetividade e aprendizagem Contribuições de Henri Wallon. São Paulo: Loyola, 2007.

ALMEIDA, M.; ELIZABETH, B.; VALENTE, J. A. Políticas de tecnologia na Educação Brasileira: histórico, lições aprendidas e recomendações. In: Centro de Inovação para a educação brasileira, 2016. Disponível em: <https://cieb.net.br/wpcontent/uploads/2019/04/CIEB-Estudos-4-Politicas-de-Tecnologia-na-Educacao-Brasileirav.-22dez2016.pdf> Acesso em: 10 mar. de 2021.

ARRUDA, Heloisa Paes de Barros. Percepção de sentimentos e emoções na videoconferência: um estudo com alunas do PEC- Municípios. Dissertação (Mestrado em Educação: Psicologia da Educação). São Paulo: Pontifícia Universidade Católica de São Paulo, 2005.

VIDEOCONFERÊNCIA E AFETIVIDADE: CAMINHOS POSSÍVEIS. Seminário em pesquisa da região sul, IX ANPED SUL, 2012. Disponível em:

<http://www.ucs.br/etc/conferencias/index.php/anpedsul/9anpedsul/paper/viewFile/907/882> Acesso em: 10 abr. 2021.

BARCELOS, Gilmara T.; BATISTA, Silvia C. F. Ensino Híbrido: aspectos teóricos e análise de duas experiências pedagógicas com Sala de Aula Invertida. Renote, V. 17 N 2 , agosto, 2019. Disponível em: <https://www.seer.ufrgs.br/renote/article/viewFile/96587/54187>. Acesso em: 20 fev. 2021.

CASTRO, Eder A.; QUEIROZ, Eliziane R. Educação à Distância e Ensino Remoto: Distinções Necessárias. Rev. Nova Paideia Revista Interdisciplinar em Educação e Pesquisa. Brasília/DF, v. 2, n. 3. Número Especial, p. 3-17, ANO 2020. Disponível em: <http://ojs.novapaideia.org/index.php/RIEP/article/view/40/31> Acesso em: 20 mar. 2021.

COLL, César. MONEREO, Carles (org.) Psicologia da educação virtual: Aprender e ensinar com as Tecnologias da Informação e da Comunicação. Porto Alegre: Artmed, 2010 . 
CETIC.BR. Pesquisa TIC Educação - 2019. [S.1.], 2020. Disponível em:

<https://cetic.br/media/analises/tic_educacao_2019_coletiva_imprensa.pdf.> Acesso em: 15 abr. 2021.

FRANCO, Maria Laura P. B. Análise de conteúdos. Brasília: Plano, 2003.

FREIRE, Paulo. Pedagogia do Oprimido. Rio de Janeiro: Paz e Terra, 1998.

INSTITUTO PENÍNSULA. Sentimento e percepção dos professores brasileiros nos diferentes estágios do coronavírus no Brasil: estágio intermediário, 2020. Disponível em: <https://institutopeninsula.org.br/wp-content/uploads/2020/08/Sentimentos_-fase-3.pdf> Acesso em: 20 jan. 2021.

KENSKI, Vani M. Tecnologias e ensino presencial e a distância. Campinas, SP: Papirus, 2003

LITTO, Frederic M.; FORMIGA, Manuel M. M. (orgs.) Educação a distância: o estado da arte. São Paulo: Pearson Education do Brasil, 2009.

MAHONEY, Abigail A.; ALMEIDA, Laurinda R. (Org.). Henri Wallon. São Paulo: Loyola, 2002.

MAHONEY, Abigail A.; ALMEIDA, Laurinda R. (Org.). A constituição da pessoa na proposta de Henri Wallon. São Paulo: Loyola, 2004.

MAHONEY, Abigail A; ALMEIDA, Laurinda R. Afetividade e processo ensinoaprendizagem: contribuições de Henri Wallon. Revista Psicologia da Educação, São Paulo, n. 20, p. 11-30, 2005.

MENEZES, Suzy K.; FRANCISCO, Deise J. Educação em tempos de pandemia: aspectos afetivos e sociais no processo de ensino e aprendizagem. In: Revista Brasileira de Informática da Educação. V. 28, 2020. P.985 - 1021. Disponível em: <https://www.brie.org/pub/index.php/rbie/article/view/v28p985> Acesso em: 20 mar. 2021.

PRANDINI, Regina C. A. R. A Teoria de Henri Wallon e a Formação de Profissionais Dedicados à Educação. Relatório de pesquisa de Pós doutorado na Educação: Psicologia da Educação. São Paulo: PUC-SP, 2020.

SANTAELLA, Lucia. A educação e o estado da arte das tecnologias digitais. In: SALES, Mary V. S. (Org.) Tecnologias digitais, redes e educação: perspectivas contemporâneas. Salvador: EDUFBA, 2020.

SANTOS, Edméa. Pesquisa-formação na cibercultura. Teresina: EDUFPI, 2019. E-book. SÃO PAULO (Estado). Decreto n 64.864, de 16 de mar. de 2020 - Estado de São Paulo. 
SÃO PAULO (Estado). Resolução SEDUC 11, de 26 de jan. de 2021 - Diário Oficial do Estado de São Paulo.

SÃO PAULO (Município). Instrução Normativa SME nº 7, de 12 de março de 2021.

TASSONI, Elvira C. M. Afetividade na aprendizagem da leitura e da escrita: uma análise a partir da realidade escolar. In: Estudos e Pesquisas em Psicologia. Rio de Janeiro: UERJ V.13, n.2, 2013. Disponível em: <https://www.epublicacoes.uerj.br/index.php/revispsi/article/view/8423/6256\#: :text=Discutir\%20a\%20afeti vidade\%20nas\%20intera\%C3\%A7\%C3\%B5es,professores\%20significam\%20as\%20experi\% C3\%AAncias $\% 20$ vividas.\&text=Essas $\% 20$ ideias $\% 20$ produzem $\% 20$ sentimentos $\% 20$ agrad $\% \mathrm{C}$ $3 \%$ A1veis,alunos\%20percebam\%20sua\%20pr\%C3\%B3pria\%20evolu\%C3\%A7\%C3\%A3o.> Acesso em: 10 mar. De 2021.

WALLON, Henri. A la lumière du marxisme. Paris. Editions sociales Internacionales, 1936 apud PRANDINI, Regina C. A. R. A teoria de Henri Wallon e a formação de profissionais dedicados à educação. Relatório de pesquisa de Pós doutorado na Educação: Psicologia da Educação. São Paulo: PUC-SP, 2020.

WALLON, Henri. Psicologia e educação da infância. Lisboa: Editorial Estampa, 1975.

WALLON, Henri. A evolução psicológica da criança. Tradução de Cristina Carvalho. Lisboa: Edições 70, 1981.

Este é um artigo de acesso aberto distribuído sob os termos da Licença Creative Commons Atribuição Não Comercial-Compartilha Igual (CC BY-NC- 4.0), que permite uso, distribuição e reprodução para fins não comerciais, com a citação dos autores e da fonte original e sob a mesma licença. 